\title{
Current energy crisis and its economic and environmental consequences: Intense human cooperation
}

\author{
Marcelo S. Sthel ${ }^{1 *}$, José G. R. Tostes ${ }^{1}$, Juliana R. Tavares ${ }^{1,2}$ \\ ${ }^{1}$ Center of Science and Technology, North Fluminense State University, Campos dos Goytacazes, Brazil; \\ *Corresponding Author: sthel@uenf.br \\ ${ }^{2}$ Coordenation of Natural Sciences and Mathmatics, Federal Institute of Education, Science and Technology, Campos dos Goytacazes, \\ Brazil
}

Received 11 December 2012; revised 15 January 2013; accepted 27 January 2013

\begin{abstract}
In this paper, the evolution of the energy use by human society is discussed, relating the energy, environmental and economic crisis, which appear to be closely linked. With the widespread use of fossil fuels since the industrial revolution, a major environmental problem was generated: the climate changes. The economic consequences of climate changes are discussed in Stern (2006). Possible solutions to confront climate change are presented in the Intergovernmental Panel on Climate Change (IPCC) report (2007). Some of these solutions are based on technological development, while others do not directly depend on the technology (paradigm shifts). Faced with the needs of a new paradigm suggested by the IPCC, the recent concept of sustainable triangular cells (2012) was introduced. The geometric representation of triangu-ar cells, which can be linked to form a regular hexagon, is used to demonstrate a sustainable society, where human cooperation prevails. This model is in line with one of the pillars of the Third Industrial Revolution, indicated by Rifkin, where an intense collaboration between individuals in human society is suggested.
\end{abstract}

Keywords: Cooperation; Sustainability; Energy Crisis

\section{INTRODUCTION}

The development of human civilization is closely linked to energy use and its multiple sources. Since the era of the early hominids on the planet, seven million years ago [1] up to the current homo sapiens, energy has been the primary factor of the species survival. Com- paring the rates of energy use by our ancestors to modern men, we noticed a significant change. Analyzing a hunting and gathering society of homo sapiens, before the advent of agriculture, we can notice that their daily energy needs were approaching 2500 kilocalories per person to hunt, fish, gather, defend and reproduce. On the other hand, the energy needs of modern men, depending on their ecological footprint [2,3] can reach more than 100 times the energy needs of the hunter-gatherer societies.

One of the most important energy source used by prehistoric man, besides the food, is the fire, obtained from dry biomass. Its use is reported for at least 500,000 years. As a source of light and heat, the fire became important for defense, protection against the cold and cooking of food. Throughout the evolutionary path, the fire is also used for heat treatment of some materials. In the social sphere, the fire introduces an important factor that defines a new space for humans around the campfire, changing the group structure, thus broadening the social contact between individuals.

Ten thousand years ago, a period known as the "Neolithic revolution" [4,5] begins. This period is characterized by a change in the use of natural resources by men. They no longer use few energy resources in hunting and gathering, but a much larger amount of resources in agriculture and livestock activities. The domain of production and reproduction of animals and plants was due to significant breakthroughs, i.e., the use of new methods and procedures for collection, transport and storage of food and new methods for food preparation. These methods were as important as the selection of animals and plants for the formation of energy-food lines.

The global domain of food chains is a radically new feature of the energy system of the Neolithic. Human energy is now applied to the cultivation of the land. The agricultural cycle is expanded and the use of energy 
becomes more complex, so that the short cycles of hunting and gathering tend to be subordinated to the longer agricultural cycles. In energy terms, in any of the cycles, human society uses an amount of energy that can be measured, and gets in return a certain food energy, which represents the energy productivity of this society. The energy era, which began with the fire (firewood), and continued which the agricultural development (food energy) enabled a major advance of civilization (cities). Both the fire and the food are renewable energies from biomass.

The great maritime discoveries of the sixteenth century were made possible by the intensive use of renewable energy, as the winds, which moved the ships built of wood, and the food, which supplied to sailors the energy needed to drive their caravels. From the seventeenth and eighteenth centuries, the first industrial revolution was made possible by the invention of the steam engine, by James Watt. Since then, the use of non-renewable energy sources, specifically the "fossil fuels" (coal, oil, natural gas) was inaugurated.

From an energy perspective, the twentieth century established the "ideology of hydrocarbons", which today are the main energy sources of the world energy matrix. Fossil fuels virtually support every economic development of the XXI Century. The intensive use of fossil fuels since the industrial revolution brought most serious environmental problems, including air pollution, which is responsible for phenomena such as acid rain, photochemical smog, global warming and many damages to human health, all widely reported in the scientific literature worldwide.

With the publication of the Intergovernmental Panel on Climate Change (IPCC) Report, in 2007 [6-8], anthropogenic global warming [9-13] was identified as the most likely cause of climate change [14-22], since the intensive use of fossil fuels produces large-scale emissions of greenhouse gases, including carbon dioxide $\left(\mathrm{CO}_{2}\right)$ and methane $\left(\mathrm{CH}_{4}\right)$. Then, we are faced with a big dilemma: we need to modify the planetary energy matrix, replacing fossil fuels for energy sources of low carbon impact. This modification will drastically change the world energy matrix, which is mainly fossil, what will bring a big impact to the world economic system. In addition, climate change can also bring great damage to the productive system. According to the Stern Report [23], we face a great civilization challenge and the twenty-first century seems to be the limit of the transition to a low carbon economy. The Stern report discusses the economic impacts of climate change and the future prospects of reaching international agreements that are truly sustainable. Chakravarty et al. [24] proposed to be taken into account the issue of individual $\mathrm{CO}_{2}$ emissions rather than by nation. This new conceptualization indicates that the richer countries have greater responsibility for greenhouse gas emissions than poorer ones. According to Jeremy Rifkin, the energy crisis is intimately linked to the environmental crisis and the economic crisis. Therefore, it is no longer possible to discuss the energy, environmental and economic crisis separately. They are closely linked and retro feed among themselves, forming what he calls as "triple trap". Rifkin points out with a proposal for a third industrial revolution [25], based on collaborative and distributive relationships, in a new green industrial era.

In this article, we also introduce the model of triangular sustainable cells proposed by Sthel and Tostes in a recent article [26]. In the vertices of the triangles, the words energy, economy and ecology (environment) are placed, proposing the inseparability of these three concepts. In this model, a regular hexagonal social organization is also proposed. In this organization, human cooperation (cultural paradigm) is an emergent property due to the complexity of today's society, enabling the sustainability of human activities.

\section{CONSEQUENCES OF CLIMATE CHANGES (IPCC): ENVIRONMENTAL IMPACTS}

Global warming is causing climate changes, producing significant consequences to human society and biodiversity, such as the poles melting, with the increasing of oceans level, increasing intensity of hurricanes, extreme events, changes in rainfall patterns (floods, desertification), oceans acidification and biodiversity decreasing [27-39].

The IPCC Report published on February 2007 (Climate Change 2007: The Physical Science Basis [6]) describes the possible impacts to the planet physical systems and produces scenarios until 2100. Eleven of the twelve years preceding the publication of the report (from 1995 to 2006) were among the 12 warmest years in the instrumental record of global surface temperature (since 1850). The global average sea level rose at an average rate of 1.8 (1.3 to 2.3) mm per year in the period 1961 to 2003 . The rate was faster over the period from 1993 to 2003, when it was about 3.1 (2.4 to 3.8) mm per year. In continental, regional and ocean basin scales, numerous longterm changes in climate were observed, which include changes in temperature and ice area in Artic, precipitation, ocean salinity, wind patterns and extreme events such as droughts, heavy precipitation, heat waves and tropical cyclones intensity. The average Arctic temperatures increased at almost twice the global average of the last 100 years. Satellite data obtained since 1978 show that the average extent of Arctic sea ice shrank by $2.7 \%$ $2.1 \%$ to $3.3 \%$ per decade, with greater reductions in the summer of $7.4 \% 5.0 \%$ to $9.8 \%$ per decade. 
From 1900 to 2005, a significant increase of precipitation was observed in eastern North America and South America, Northern Europe, Northern Asia and Central Asia. More intense and longer droughts were observed over wider areas since 1970, specially in the tropics and subtropics. Changes in precipitation and evaporation over the oceans are suggested by freshening of mid- and high-latitude waters together with increased salinity in low-latitude waters.

The IPCC Report published in April 2007 [7] (Climate Change 2007: Impacts, Adaptation and Vulnerability) describes the possible impacts of global warming on human society and ecosystems, producing scenarios until 2100. Some effects in the natural environment and human development are emerging such as the changes in agricultural and forestry management in the higher latitudes of the northern hemisphere, the anticipation of the spring crops planting and changes in disturbance regimes of forests due fires and pests. Settlements in mountain regions are at greater risk of floods by glacial lakes disruption caused by melting glaciers. In the Sahel, region of Africa, warmer conditions and drought caused a reduction of the growing season duration with detrimental effects on crops. These densely populated and low lying areas, where adaptive capacity is relatively low, already face other challenges, such as tropical storms or local coastal subsidence, are more at risk. The number of people affected will be greater in large deltas of Asia and Africa while small islands are especially vulnerable. Observing the health aspect, there will be an increasing number of deaths, diseases and injuries because of heat waves, floods, storms, fires and drought, increased frequency of respiratory diseases because of the higher concentration of ozone, which is closely associated with the climate change and altered spatial distribution of some infectious disease vectors.

\section{Proposals to Reduce Emissions of Greenhouse Gases (IPCC)}

The IPCC Report [8] (Climate Change 2007: Mitigation of Climate Change) reveal that the use of the key mitigation technologies and practices by sector (Technological Solutions) and Non-technological practices, such as lifestyle changes (cultural paradigm), are of fundamental importance for the reduction of greenhouse gases. Among the technological practices by sector already available nowadays, we can mention: a) Energy Supplyimproved supply and distribution efficiency; fuel switching from coal to gas; nuclear power; renewable heat and power (hydropower, solar, wind, geothermal and bioenergy); combined heat and power; early applications of Carbon capture and storage-CCS (e.g. storage of removed $\mathrm{CO}_{2}$ from natural gas); b)Transport-more fuel efficient vehicles; hybrid vehicles; cleaner diesel vehicles; biofuels; modal shifts from road transport to rail and public transport systems; non-motorized transport (сусling, walking); land-use and transport planning; c) Buildings - efficient lighting and day lighting; more efficient electrical appliances and heating and cooling devices; improved cook stoves, improved insulation; passive and active solar design for heating and cooling; alternative refrigeration fluids, recovery and recycle of fluorinated gases; d) Industry-more efficient end-use electrical equipment; heat and power recovery; material recycling and substitution; control of non- $\mathrm{CO}_{2}$ gas emissions; and a wide array of process-specific technologies; e) Agriculture-improved crop and grazing land management to increase soil carbon storage; restoration of cultivated peaty soils and degraded lands; improved rice cultivation techniques and livestock and manure management to reduce methane emissions; improved nitrogen fertilizer application techniques to reduce nitrous oxide $\left(\mathrm{N}_{2} \mathrm{O}\right)$ emissions; dedicated energy crops to replace fossil fuel use; improved energy efficiency; f) Forestry—afforestation; reforestation; forest management; reduced deforestation; harvested wood product management; use of forestry products for bioenergy to replace fossil fuel use; g) Waste-landfill methane recovery; waste incineration with energy recovery; composting of organic waste; controlled waste water treatment; recycling and waste minimization.

The non-technological practices (changes in lifestyle and behavior patterns) can contribute to climate change mitigation across all sectors, a genuine change in cultural paradigm practices with: 1) Lifestyle changes can reduce greenhouse gases (GHG) emissions. Changes in lifestyles and consumption patterns that emphasize resource conservation can contribute to developing a low-carbon economy that is both equitable and sustainable; 2) Education and training programs can help overcome barriers to the market acceptance of energy efficiency, particularly in combination with other measures; 3) Changes in occupant behavior, cultural patterns and consumer choice and use of technologies can result in considerable reduction in carbon dioxide emissions related to energy use in buildings; 4) Transport Demand Management, which includes urban planning (that can reduce the demand for travel) and provision of information and educational techniques (that can reduce car usage and lead to an efficient driving style) can support GHG mitigation; 5) In industry, management tools that include staff training, reward systems, regular feedback, documenttation of existing practices can help overcome industrial organization barriers, reduce energy use, and GHG emissions. All proposals submitted in the IPCC Report [8] are within the capitalist economic matrix and are based on the concept of sustainability, but are difficult to be implemented in practice, especially if we use only the technological so- 
lutions available. We need urgent cultural change that leads us to an era of intense human cooperation [26] (cultural emergency) that is contrary to the current economic model, that is, which calls for intense competition. A device of human cooperation, which has been used many times by homo sapiens during its evolution and that was crucial to its consolidation as the dominant species, is the device of the "Cultural Damping" $[40,41]$. This is a factor in the behavior of a group (in the form of social, technological and cultural organization) that serves as a guarantee of their bets on risky game of natural selection. To face the fearsome climate change, which is one of the great challenges of the XXI Century, we have to use damping mechanisms similar to that used by homo sapiens during the construction of its civilizing process.

\section{STERN REPORT, ECONOMIC IMPACTS AND PROSPECTS FOR AGREEMENTS ON CLIMATE CHANGE}

The "Stern Review" [23], published in late 2006, and the "IPCC Report" [6-8], published in the first half of 2007 are part of the ascending phase (2006-2007) of an "environmental capitalist mini-cycle" (2006-2009), which is included, in turn, in the greater trajectory of the capitalist economic matrix [42]. Surely unprecedented in its history, the capitalist system starts-from 2006-the internalization of the environmental costs particularly triggered by the effects of global warming from the emission of "greenhouse gases" by the industrial developed countries. With the emergence of so-called "financial crisis" in the end of 2007, the aforementioned mini cycle enters its descending phase (2008-2009), once the economic matrix essentially go back to its pre-2006 procedures until the present day, with respect to the environment. There are no signs of return in the short term to something that resembles the ascending phase of the mini cycle. The "Stern Review", headed by Nicolas Stern, commissioned by the British government, proposed a profound articulation Economy-Environment, unlike what is commonly found in reports commissioned by large capitalist governments. The report analyzes various climate scenarios derived by global warming (for different levels of greenhouse gas emissions that extend until 2050) and possible economic effects associated with each one of them. From this level, Stern confronts the historical trend in the economy "externalization" of social and environmental costs that this economic system is producing via effects of global warming (there are strong possibilities, such as those designed scenarios - to cause soon a monumental future recession) and the proposal of investments planned and financed by the central countries (at costs much lower than that likely recession) spe- cifically aimed at reducing emissions of greenhouse gases and to minimize the possible macroeconomic and social consequences (especially in relation to the poorest ones).

Turning to the numbers of the 2006 report, Stern estimated that in 40 years (i.e. up to 2050) $20 \%$ of global Gross Domestic Product (GDP) would be needed to cover the costs generated by climate effects under discussion ("business as usual"). Moreover, by 2050, only 1\% of global GDP would be needed to reduce greenhouse gas emissions on the planet and avoid a coming catastrophic recession. Later, in 2008, he would reassess up such costs [43].

In the first half of 2007, the already mentioned Fourth IPCC Report [6-8] is published, demonstrating progress towards climate scenarios described by Stern. Even taking into account that the writing of the report was probably influenced by the governments involved, this report was a landmark and irreversible document, once it refers not only to the threats of the sustainability of the planet (environment), but to the economic system itself (economics), which will have to face such threats over the XXI Century if the traditional "outsourcing" of environmental costs persists. We must be critical, however, about a kind of "decision" on the end of the IPCC Report establishing a possible sustainable climate scenario for the planet ("possible" to provide political and economic conditions to be effected). This scenario suggests reducing emissions of future carbon at a given threshold, so that the temperature of the planet would not increase more than two degrees on average during the period from 1800 to 2100 . Should our environmental future be decided by the governments of developed countries, legitimated by a scientific report? Through documents like the IPCC Report, compensation mechanisms "cap and trade" (articulating market-state) emerge, and many countries choose to continue polluting in the name of "economic development" and their own profits. More specifically, we are talking about producers who emit greenhouse gases in excess and the costs of such excess shall be "governed by the market" through a "Clean Development Mechanism" (CDM). The best known CDM is the "market for carbon credits". The English writer George Monbiot [44] compares carbon credits with the purchases of indulgence in medieval Catholic Europe. Buy the right to pollute is like buying pardons, and then we must stop creating false markets [45]. Similarly to the Stern and IPCC Reports is the report of the World Bank (The cost to developing countries of adapting to climate changes; New Methods and Estimates) [46]. Its objective "is to develop an estimate of adaptation costs for developing countries". The report, which focuses on this objective, "finds that the cost between 2010 and 2050 of adapting to approximately $2^{\circ} \mathrm{C}$ (since pre-industrial era 
up to 2050) warmer would by 2050 is in the range of $\$ 75$ billion to $\$ 100$ billion a year”.

Within a critical stance regarding environmental issues, we highlight Chakravarty's article [24], with the collaboration of scientists as Pacala and Sokolow also focused on global warming and global mechanisms of reduction of greenhouse gas emissions (in this article, the concept of "common but differentiated responsibilities" refers to the emissions of individuals instead of nations). The purpose of this article is more adherent to the position of poor countries in the discussion of the COP's and more adherent to the concept of "eco-development", developed by Sachs in the 80's [47] than the concept of "sustainable development," suggested by the Bruntdland Report [48]. That proposal [24], even within the borders of the current economic system, proceeds to an agreement on emissions of greenhouse gases mechanism via "social classes", i.e. it proposes to divide in a "fair" the responsibility of emission cuts, not via fixed and universal reduction factor, but focusing on different factors in each country, depending on the polluting degree of the industrial energy matrix of each country and depending on the energy consumption of its respective social classes. In this case, the poorest of the poor countries should be allowed to-for a time - to issue more than ever to emit, to allow them to develop.

Another article, authored by J. Rockstrom et al. [49], was published in Nature, with posture of a true manifest. This "article manifest" (reminiscent of the famous article about "nuclear winter" that lists various scenarios of explosions of nuclear weapons [50]), exposes not just one, but nine tended global threats to the environment, all of which are caused largely by technological model of cartesian linear-exploitation of natural resources in the economic system. What would be the stability of this system if he saw led to internalize, at least in part, the environmental costs of all these nine planetary threat vectors? The real face of political and economic global environmental issue has lost part of its broad thrust of 2006-2007, through successive United Nation Climate Change Conferences (COP) and other large bodies worldwide, mainly due to the expansion of the international economic crisis from 2008 to 2009. Everything is indicating that there is no safe prediction on when there will be another similar agreement, at least to Kyoto. The COP-Doha (2012), recently concluded, has at least prorogated the Kyoto Protocol, with a minor number of participants, but with a more advanced aggregate target in reducing $18 \%$ of greenhouse gases emissions between 2013 and 2020, as regards the 1990 levels.

Moreover, the recent disclosure by the Secretariat of the "United Nations Convention on Climate Change" on the national amounts of greenhouse gases from "developed” countries (listed in Annex 1 of that Convention) issued in the period 1990-2010 presented results that seem encouraging: average reduction of about $14 \%$ with respect to those emissions which were presented in 1990 (Kyoto Agreement established a reduction of 5.2\% relative to 1990). However, one must be careful in interpreting the figures presented by the Convention. For example, within the list of signatory countries called "developed" appears great Russia, encompassing the former Soviet republics, which have significantly reduced emissions compared to 1990 as a result of its sharp economic decline in part of the considered period. We also emphasize that, within this clash (economic versus environmental crises), there will be a new IPCC Report in 2013. To summarize important insights of researchers/consultants of complex environmental issues, we have: a) I. Sachs, whose model of "eco-development" of the 70's contrasts the model of "sustainable development" of the Brundtland Report, being more socially advanced; b) Nicolas Stern, whose report, at the end of 2006, even within current economic patterns, brought to the world of official government policies a text that articulates economy and environment, by proposing a policy of internalization of the environmental costs of global warming, generated largely by the effects of greenhouse gas emissions from large industry of developed countries; c) The Chakravarty article, which proposed a model of sharing cuts/releases of greenhouse gas emissions, which is distinguished from the vast majority of the current models of cutting emissions by a greater concern with poor people. These three statements above indicate, ultimately, proposals which are very close to the boundaries of possible environmental actions in the current economic system.

\section{RIFKIN'S THIRD INDUSTRIAL REVOLUTION}

In a recent book titled "The Third Industrial Revolution”, Jeremy Rifkin [25] proposes the five basic pillars of this new revolution: 1 ) the shift to renewable energy; 2) the transformation of real property of each continent in micro generators of energy to collect local renewable energy; 3) the use of hydrogen and other storage technologies in every building and throughout the infrastructure to store intermittent energies; 4) the use of internet technology to transform the power grid of the entire continent in a power-sharing network that acts like internet (sharing power); 5) make the transition of the transport fleet to vehicles powered by fuel or electric cells and promote the sale of electricity in a interactive, continental and smart power grid. These proposals have a strong technological component to achieve this new industrial revolution.

The conventional organization of society, from top to bottom, which characterized the economic, social and 
industrial revolutions policy based on fossil fuels, must yield to the distributive and collaborative relationships of the emerging new green industrial era. This model is in the midst of a profound change in the way society is structured, distant of the hierarchical power and toward to the side power. In this new collaborative phase of human society, highlighted in the proposal of a new industrial revolution, our sense of responsibility and relationship with other human is modified and we spend worrying about our common destiny. Share renewable energy more collaboratively, creating an identity as a species in a nascent awareness of the interconnectedness, helps us to be part of the same biosphere. The pursuit of quality of life, however, suggests a new vision of the future, based on collaborative interest in connectivity and interdependence, which can only be experienced collectively. This leads to proposals with a non-technological component, based on human behavior, with a new cultural paradigm centered on human collaboration in order to achieve more efficiently this new industrial revolution.

If the earlier industrial eras emphasized values of discipline and hard work, the top-down authority, the importance of financial capital, market functioning and relations of private property, the collaborative era translates into creative play, interactivity among peers in the social capital, the community use of natural resources, stand in our society regular hexagonal model [26] and the access to global networks. The third Industrial Revolution will move quickly in the coming decades, probably stabilizing, according to Rifkin, the second half of the century. Then, a new economic era that will take us beyond the industrial mode that characterized the last two centuries of economic development and will enter a collaborative way of life. The metamorphosis to the Third Industrial Revolution will represent a major landmark in the economic history of the XXI century.

In this new industrial revolution, economic concepts should be reassessed, once Adam Smith exalted the systematization of the universal physics by Newton as "the greatest discovery made by man" and used metaphors of Principia and other Newton's books to develop the classical economic theory. In Newtonian physics, any system is theoretically reversible in time, because the laws of matter in motion do not grant the passage of time. But the real economic activities deal with the irreversibility of events and with the manner whereby material resources are harnessed, processed, used and discarded. Only by the second half of the nineteenth century the laws of thermodynamics were developed: the two energy laws (energy conservation and dissipation). Thus, economists had scientific basis to describe with a supposed accuracy the economic activity. The first effort to introduce the laws of thermodynamics in economic theory, contrary to the dominant articulation between Newtonian mechanics and capitalist economy, was made by Fredrick Soddy in his book of 1911, Matter and Energy [51]. But the first economist to have historical conditions (including the nascent environmental issue) to sustainably introduce this new vision was Nicholas Georgescu-Roegen. Roegen published in 1971 the book “The Entropy Law and the Economic Process” [52], which were dismissed by most economists of the classical view. In recent years, with the advancement of sustainability issues, especially those centered on concerns related to energy and climate change, new criticisms of the classical and neoclassical economic theory have been made, in opposition to the laws of classical thermodynamics. We now move to a new economic, ecological and sustainable energy vision of the industrial revolution, where the Newtonian paradigm of science will be reassessed, enabling the emergence of a new systemic paradigm of science, where new frontiers of thermodynamic (from classical or equilibrium thermodynamics until non equilibrium thermodynamic) emerge [53].

\section{SUSTAINABLE COMPLEX TRIANGULAR CELLS: HUMAN COOPERATION}

Recently, the concept of "sustainable complex triangular cells” [26] was developed. This concept uses a simplified geometric model, which aims to facilitate the understanding of the serious current environmental problems and their growing complexity, which represent the coupling between human and the natural systems. The areas of the triangles represent the ecological footprint of individuals in today's society. At the vertices of these triangles the words energy, economy and environment are placed, indicating the inseparability of these concepts today. These are scalene triangles to denote the asymmetry of these concepts, especially conflicts between economy and environment. But, using the concept of sustainability of [26], within a first geometric transformation, the scalene triangle can be transformed into equilateral, enabling a more harmonious relationship between economy, energy, environment, mainly through technological transformations.

However, to attain a consistent sustainability that can equate the complexity of environmental issues (climate change), human cooperation on a large scale must be used with new cultural paradigm. This structure was proposed by pictorial feature a regular hexagonal structure whose total area is smaller than the sum of equilateral triangles that generated it. Reducing the carbon footprint of this community means hexagonal strengthen relationships between individuals (cooperation) that compose this structure, making it more sustainable. This model represents a sustainable social system that: i) con- 
tinue to exchange energy and matter with their environment, i.e. it is structurally open; ii) but it has a growth pattern (network) closed, being a self-organizing system [54]. From the chaotic structure of the current model of asymmetric scalene triangles, order can be generated through a non-deterministic change in the cultural paradigm, which leads to the emergence of a new selforganizing system. This new order is obtained through regular hexagonal relations, which enable coupling indefinitely, until the formation of self-assembled representations of large numbers of individuals, i.e. the hexagonal coupling, which is similar to the device of cultural damping [40,41]. Thus, the interdependence between individuals that compose the set of regular hexagons is maintained, forming a network structure, which share resources and environmental services in a truly sustainable way. As an example of natural life, we have the complexity $[55,56]$ of a school of fish, which organizes itself, to become defended from predators. This is an example of the use of "collective intelligence" [57-62], which is also used by the homo sapiens.

Following the guidelines of the non-technological IPCC proposals, which indicate the possibility to reduce emissions of greenhouse gases by changing patterns of human behavior, we propose the development of a stronger cooperation among the members of our species. The regular hexagonal model of society was applied in order to reduce the ecological footprint of this society with regard to the use of fossil energy and hence a considerable reduction in greenhouse gas emissions.

The remarkable economic and social scenario designed by Rifkin, highlighting the cooperation factor is in line with the regular hexagonal model society, because the concepts used in the construction of the model recommend an intense human cooperation, which is close to the concept of the collaborative phase of human society, proposed by Jeremy Rifkin. Another factor to be noted is the inseparability of the energy, economic and environmental crises, that feedback themselves and do not have separate solutions, according to Rifkin. It is also proposed in the model of sustainable triangular cells by Sthel/Tostes. The proposals so far presented are consistent with the solutions proposed by the IPCC, i.e., technological and non-technological guidelines to reduce emissions of greenhouse gases sustainably.

\section{CONCLUSIONS}

The current global energy matrix, centered on the intensive use of fossil fuels, produces an environmental crisis unprecedented in human society, the dreaded climate change. According to the Stern report, this crisis could seriously jeopardize the global economy in the twenty-first century. These crises are interconnected and do not have separated solutions in a projection of the new industrial revolution, which is a conceptual and technological revolution.

A more collaborative phase of human society would emerge from this new Rifkin's industrial revolution proposal. Therefore, the concept of a social organization based on intense human collaboration, proposed by Sthel/Tostes can be applied. This model uses sustainable triangular cells, which are associated to form a hexagonal structure, where the cooperation between individuals prevails. The association of hexagonal structures allows the structural organization of human society, which can be represented as a beehive. By sharing resources in a sustainable manner, society would apply the concept of cultural damping, already used on major environmental challenges.

\section{ACKNOWLEDGEMENTS}

The authors would like to thank the Brazilian agencies CNPq, FAPERJ and CAPES for the financial support.

\section{REFERENCES}

[1] Brunet, M., et al. (2002) A new hominid from the Upper Miocene of Chad, Central Africa. Nature, 418, 145-151. doi:10.1038/nature00879

[2] WWF-World Wild Life Foundation (2006) Report for a living planet. Global Footprint Network, Switzerland.

[3] Dias, G.F. (2006) Human ecological footprint and sustainability. Gaia, São Paulo.

[4] Childe, G. (1961) The history movement. Arthaud, Paris.

[5] Lee, R. and DeVore, I. (1968) Man the hunter. Aldine Atherton, Chicago.

[6] IPCC (2007) The physical science basis. Report of Working Group I, Paris.

[7] IPCC (2007) Impacts; adaptation and vulnerability. Report of Working Group II, Brussell.

[8] IPCC (2007) Mitigation of climate change. Report of Working Group III, Bangkok.

[9] Meinshausen, M., et al. (2009) Greehouse-Gas emission targets for limiting global warning to $2{ }^{\circ} \mathrm{C}$. Nature, 458, 1158-1162.

[10] Myles, et al. (2009) Warning caused by cumulative carbon emissions towards the trillionth tonne, Nature, $\mathbf{4 5 8}$ 30.

[11] Hansen, J., et al. (2008) Target atmosphere $\mathrm{CO}_{2}$ : Where should humanity aim. The Open Atmospheric Science Journal, 2, 217-231.

[12] Hansen, J. and Makiko (2004) Greenhouse gas growth rates. PNAS, 101, 16109-16114. doi:10.1073/pnas.0406982101

[13] Lacis, A.A. (2012) Greenhouse effect. In: Liu, G., Ed., Greenhouse Gases-Emissions, Measurement and Manager, Intech, Crocia.

[14] Solomon, S., et al. (2009) Irreversible climate change due to carbon dioxide emissions. PNAS, 106, 1704-1709. 


\section{doi:10.1073/pnas.0812721106}

[15] Trenberth, E.K., Moore, B., Karl, T.R. and Nobre, C. (2006) Monitoring and prediction of the earth's climate: A future perspective. Journal of Climate Special Sections, 19, 5001-5008.

[16] Mann, M.E., Bradley, R.S. and Hughest, M.K. (1998) Global temperature patterns and climate forcing over the past six centuries. Nature, 392, 779-787. doi:10.1038/33859

[17] Hansen, J. and Nazarenko, L. (2004) Soot climate forcing via snow and ice albedos. PNAS, 101, 423-428. doi:10.1073/pnas.2237157100

[18] Hansen, J., et al. (2005) Earth's imbalance: Confirmation and implications, Science, 308, 1431-1435. doi:10.1126/science.1110252

[19] Trenberth, E.K., Moore, B., Karl, T.R. and Nobre, C. (2006) Monitoring and prediction of the earth's climate: A future perspective. Journal of Climate Special Section, 19, 5001-5008.

[20] Cziczo, D.J. (2009) Inadvertent climate modification due to anthropogenic Lead. Nature Geoscience, 499, 1-4.

[21] Coumou, D. and Rahmstorf, S. (2012) A decade of weather extremes. Nature Climate Change, 2, 491-496.

[22] Jarvis, A.J., Leedal, D.T. and Hewitt, C.N. (2012) Climate-Society feedbacks and the avoidance of dangerous climate change. Nature Climate Change, 2, 668-671.

[23] Stern, N. (2006) Stern review: The economics of climate change, UK.

[24] Chakravarty, S., et al. (2009) Sharing global $\mathrm{CO}_{2}$ emission reductions among one billion high emitters. PNAS, 106, $1-5$.

[25] Rifkin, J. (2012) The third industrial revolution: How lateral power is transforming energy, the economy, and the world. M. Book do Brasil Editora, São Paulo.

[26] Sthel, M.S. and Tostes, G. (2012) Sustainable complex triangular cells: Case study-Envira River isolated Indians in Western Amazon. Journal of Sustainable Development, 5, 92.

[27] Trenberth, K.E. and Shea, D.J. (2006) Atlantic hurricanes and natural variability in 2005. Geophysical Research Letter, 33, 1029. doi:10.1029/2006GL026894

[28] Nathan, P., et al. (2008) Attribution of polar warming to human influence. Nature Geoscience, 1, 750-754.

[29] Siddall, M., Stocker, T.F. and Clark, P.U. (2009) Constrains on future sea-level from past sea-level change. Nature Geoscience, 2, 571-575. doi:10.1038/ngeo587

[30] Sander, B.D., et al. (2006) Forced and ungforced ocean temperature changes in Atlantic and Pacific tropical cyclo genesis regions. PNAS, 103, 13905-13910.

[31] Emanuel, K. (2005) Increasing destructiveness of tropical cyclones over the past 30 years. Nature, 436, 686-688.

[32] Peza, A.B. and Simmonds, I. (2005) The first South Atlantic hurricane: Unprecedented blocking, how shear and climate change. Geophysical Research Letters, 32, 5712.

[33] Janssen, M. (1998) Use of complex adaptive systems for modeling global Change. Ecosystems, 1, 457-463. doi:10.1007/s100219900041

[34] Kurz, W.A., et al. (2008), Mountain pine beetle and forest carbon feedback to climate change. Nature, 452, 987-990. doi:10.1038/nature06777

[35] Greene, C.H., Monger, B.C. and McGarry, L.P. (2009) Some like it cold, northern shrimp stocks thrive when climatic conditions lead to cold bottom waters. Science, 324, 733-734.

[36] Munson, L., et al. (2008) Climate extremes promote fatal co-infections during canine distemper epidemic in African Lions. Plos One, 3, 1-6. doi:10.1371/journal.pone.0002545

[37] Lenoir, J., et al. (2008) A significant upward shift in plant species optimum elevation during the 20th century. Science, 320, 1768-1771. doi:10.1126/science.1156831

[38] Kevin, J.F., Jerry, C.B., Mark, E.B., John, A.R., Darren, R.C., John, B. and Glen, L.W. (2012) Changes in pH at the exterior surface of plankton with ocean acidification. Nature Climate Change, 2, 510-513.

[39] Rosenzweig, C., et al. (2008), Attributing physical and biological impacts to antropogenic climate change. $\mathrm{Na}$ ture, 453, 353-357.

[40] Hall, S.S. (2008) Neanderthals. National Geographic.

[41] Kuhn, S.L. and Stiner, M.C. (2006) What's a mather to do! The division of labor among Neanderthals and modern humans in Eurasia. Current Antropology, 47, 953-981. doi:10.1086/507197

[42] Dias, G.V. (2009) Capital, and environmental complexity: A study of the environmental crisis of the capitalist system (1930-2013). Máster Dissertation, Postgraduate Program in Environmental Science, UFF.

[43] Marconde, D. and Ribeiro, D. (2009) The end of a Pôster. Carta Capital, 567, 61-67.

[44] Monbiot, G. (2004) Heat; How to prevent the planet. ARDA, Portugal.

[45] Sachs, I. (2009) The energy of tomorrow. Carta Capital, 567, 54-57.

[46] (2009) The global report of the economics of adaptation to climate change study. World Bank, Copenhagen.

[47] Sachs, I. (1991) Ecodevelopment: Grow without destroying. Vértice, São Paulo.

[48] (1987) Report of the world commission on environment and development: Our common future report. ONU, Brundtland.

[49] Rockstrom, J., et al. (2009) A safe operating space for humanity. Nature, 461, 472-475. doi:10.1038/461472a

[50] Sagan, C., et al. (1983) Nuclear winter: Global conesquences of multipli nuclear explosions. Science, 222, 1283-1202. doi:10.1126/science.222.4630.1283

[51] Soddy, F. (1911) Matter and energy. Henry Holt and Company, New York.

[52] Georgescu-Roegen, N. (1971) The entropy law and the economic process. Harvard UP, Cambridge.

[53] Prigogine, I. and Stengers, I. (1984) Order out of chaos: Man's new dialogue with nature. Bantam Books, New York.

[54] Bak, P. (1996) How nature works: The science of self- 
organized criticality. Copernicus Books, New York.

[55] Watkins, N.W. and Mervyn (2008) Natural complexity. Science, 30, 18.

[56] Ashley, J.W., et al. (2008) Quorum decision-making facilitates information transfers in fish shoals. PNAS, 105, 6948-6953.

[57] Patten, B.C. (1991) Network ecology. In: Higashi, M. and Burns, T.P., Eds., Theorical Studies of Ecosystems: The Nework Perspective, Cambridge University Press, New York.

[58] Parrish, J. K. and Edelstein-Keshet, L. (1999) Complexity, pattern, and evolutionary trade-offs in animal aggregation. Science, 284, 99-101. doi:10.1126/science.284.5411.99

[59] National Geographic (2007) Collective intelligence.

[60] News (2007) All Together now-pull. Science, 317, 13381340.

[61] Brown, P. and Lauder, H. (2000) Collective intelligence. In: Baron, S., Field, J. and Schuller, T., Eds., Social Capital: Critical Perspectives New York, Oxford University Press, Oxford.

[62] Sunstein, C. (2006) Infotopia: How many minds produce knowledge. Oxford University Press, Oxford. 